\title{
The Federal Administration as an Actor in the Domestic Integration of International Law
}

\author{
Sophie Weerts and Amalia Sofia
}

\subsection{INTRODUCTION}

The twentieth century witnessed a remarkable expansion of international law, and the Swiss federal constitution of 1999 expresses a strong commitment to international cooperation and respect for international law (Rhinow and Schefer 2009: 696 et seq). Nevertheless, the Swiss legal system is distinctive in its commitment to using direct democratic instruments. Indeed, together with federalism and neutrality, direct democracy has become one of the founding myths of Swiss constitutional identity (Hertig Randall and McGregor 2010: 429).

Yet in recent decades, direct democracy has been increasingly seen as potentially threatening to the coherence of Swiss foreign policy (Federal Council 1997: 445; Haller 2016: 38). Swiss public administration faces a dilemma here. On the one hand, it must comply with the rule of law, applying the principle of legality and respecting international law (Art. 5 (1) and (4), Swiss Federal Constitution, henceforth Const.). On the other

S. Weerts $(\varangle) \bullet$ A. Sofia

IDHEAP, University of Lausanne, Lausanne, Switzerland e-mail: Sophie.Weerts@unil.ch; amalia.sofia@unil.ch

(C) The Author(s) 2019

105

A. Ladner et al. (eds.), Swiss Public Administration, Governance and Public Management, https://doi.org/10.1007/978-3-319-92381-9_6 
hand, it must simultaneously recognize the people's will expressed at the polls if it is to keep the citizens' trust in the system. This chapter intends to show how the federal administration, guided by Swiss law, plays a role in maintaining a balance between direct democracy and respecting international law. It will not offer a detailed description of the rules and practices regulating the relationship between international and domestic law. Instead, it focuses on the legal and political mechanisms which influence how international and Swiss law are articulated in a manner which ensures respect for the country's 'monistic' tradition. A monistic tradition means that international law is part of the domestic legal order, so new obligations created by treaty do not have to be 'incorporated' into national legislation (Haller 2016: 19).

We begin by briefly defining the constitutive mechanisms involved in the development of international law and direct democracy in contemporary Swiss law. Next, we examine the current ratification procedure for international treaties before turning to the implementation phase of international law. In our conclusion, we identify the strengths and weaknesses of the Swiss system, especially in the face of opposition from international law.

\subsection{International LaW and Direct Democracy as Constitutive Elements of the Swiss Political SySTEM}

\subsubsection{The Development of International Law}

After World War II, the main purpose of international treaties was no longer to define geographic borders or regulate peace negotiations, but rather to institutionalize international organizations. These newly created multilateral bodies quickly became a locus producing, coordinating and interpreting international norms. Such international fora have become a privileged location for discussing and regulating a growing number of important policy issues, while also benefiting from the participation of each state. The development of international law takes different shapes and forms which include international treaties, recommendations, guidelines and other soft law instruments (see Flückiger in this volume). This results in a sharp increase of norms and actors in the field of public international law. These norms can have an effect on the activities of states, their administrations and even on the legal situation of private individuals, if treaties include directly applicable provisions (Mader 2013: 247). 
Such developments have been taken into account in Swiss constitutional law, particularly in the 1999 complete revision of the Swiss constitution which included a number of new provisions related to international law (Haller 2016: 37). As noted, the Confederation and the cantons 'respect international law' (Art 5 (4) Const.) (Aubert and Mahon 2003: 48 et seq). The Confederation is 'committed...to a just and peaceful international order' (Art. 2 (4) Const). Mandatory provisions of international law also must not be violated when changing the constitution (Art. 193 (4) and Art. 194 (2) Const.). The federal Supreme Court and other judicial authorities 'apply federal acts and international law' (Art. 190 Const.). All these provisions express Switzerland's strong commitment towards international law.

Moreover, the number of texts in force for international law is higher than for domestic law (Federal Council 2016a). Switzerland signed and ratified 121 Council of Europe conventions (Federal Council 2016a: 6828). Switzerland, however, chose not to become a member of the EU, opting instead for a 'bilateral path' (Maiani and Bieber 2016; Maiani 2013 ) involving numerous individual agreements with the EU which cover a wide array of issues and policies. In that context as well, European law is pervasive and very evident in Swiss law (Maiani 2013).

\subsubsection{The Development of Direct Democracy}

Direct democracy is one of the hallmarks of the Swiss legal and political system. It allows Swiss citizens to participate in the lawmaking process as well as in revising the constitution. This can be done either to encourage political action (popular initiative) or to alter political actions already taken (via referendum). (Art. 138 to 142 Const.). Also referred to as 'popular rights', the mechanisms of direct democracy exist at communal, cantonal and federal levels. Historically, they emerged first at the cantonal level and were only gradually established at the federal level to complement the system of representative democracy. Switzerland has gradually increased the use of referenda, thereby compensating for the reduced possibility of popular participation in decision-making processes at the international level (Hertig Randall 2016: 166). Changes introduced in 1999 and 2003 gave parliament a right to participate when international treaties were concluded (Federal Council 1997: 231), and popular rights were modified. Democratic participation in international treaties was thereby brought into line with participation in national legislation (Federal Council 2001: 5795). 
To date, while the right to launch an initiative is limited to domestic matters (e.g., it can be used only for the adoption of norms on the constitutional level), referenda can-and in some cases must-be held about international matters such as treaties (optional referendum for specified kinds of treaties) or joining a supranational community (mandatory referendum) (Art. 140 and 141).

\subsection{The Role of the Federal Administration in the Accession to International Treaties}

The UN's Vienna Convention on the Law of Treaties (23 May 1969) sets out the accession procedure to international law for states. When acceding to a Convention, a state either adheres outright to the treaty, thereby indicating it will commit to it, or signs the treaty, pending internal examination. It will then later ratify it. The Vienna Convention leaves it to each state to determine domestically which organs are given the competency to participate on behalf of the government.

Switzerland has a signature phase and a ratification phase (Art. 184 (2) Const.), but the procedure it adopts, and the internal actors involved, can vary according to whether the treaty is bilateral or multilateral.

\subsubsection{Signature}

The Federal Council is responsible for foreign relations (Art. 184 (1) Const.) and represents Switzerland abroad (Art. 54 (1) Const.). It has the general competence to sign and ratify international treaties (Art. 184 (2) Const.). In some instances, the treaties must be submitted to the Federal Assembly for approval before ratification. The Federal Council can also delegate the concluding of a treaty to a relevant department or office- of the federal administration (Art. 48a GAOA). If an international negotiation is launched, a negotiating mandate is issued by the Federal Council. The negotiating minister must then consult the parliamentary committees responsible for foreign relations, allowing the negotiator to establish the main outlines and directives of the mandate (Art. 152 (3) Federal Act on the Federal Assembly).

In practice, the procedure combines legal rules and certain processes, providing a guide for public action, though the Federal Council must play a nuanced role. The cantons can themselves play an active role internationally by being associated with a foreign policy decision by the national executive 
(Art. 55 (3) Const.), and even conclude international treaties in matters falling within their competences. Nevertheless, cantons must act in such a way to ensure the coherence of the Swiss external policy. Their international commitments cannot be contrary to the interests of the Confederation: therefore, prior to the conclusion of a treaty, the federal authority must be informed (Art. 56 Const.; Art. 61c and 62 GAOA; Art. 27o and 27 t of the Ordinance on Government and Administration Organization). If the Federal Council was to consider this cantonal engagement to be against the nation's interests, the Federal Assembly is notified (Art. 186 (3) Const.). The latter shall then give its approval to the convention (Art. 172 para. 3 Const.; Haller 2016: 250; Ziegler 2015: 88). Furthermore, if a field of cantonal competence is covered by the new international norm, cantons may also take part in the negotiation (Art. 55 Const.; Federal Act on the Consultation Procedure). The impetus to the signature of an international treaty can thus come from the Federal Council itself, from the Federal Assembly, or from a canton (Federal Department of Foreign Affairs 2015: 9).

That being said, the proposal to sign generally comes from the Department of Foreign Affairs and, in some cases, other federal departments when the treaty in question falls within their competence (Federal Department of Foreign Affairs 2015: 9). Furthermore, prior to the signature, a collaborative process takes place during which there are many exchanges between the Federal Council, the Federal Assembly and the cantons (and sometimes social and professional organizations) under the aegis of the federal administration. The Department of Foreign Affairs, in particular, early on played the role of general guardian of the development of international law ('juridical conscience'). This role has been remarkable in the treaties adopted within the Council of Europe, and according to Art. 3 of the Statute of the Council of Europe, Switzerland agreed to 'collaborate sincerely and effectively' in the realization of the organization's goals. Accordingly, the Federal Administration follows the Council of Europe's work closely, and, since 1976, a yearly report on 'Switzerland and the Council of Europe's Conventions' have been published. This document provides the reasons why Switzerland should or should not adhere to Conventions elaborated within the Council of Europe. The report is drafted by the offices in the federal administration and then submitted to the Federal Assembly via a preliminary report provided by the Federal Council.

The Federal Council, supported by the federal administration must base its proposal on measurable elements defined in 1969 (Federal Council 2016a: 6829). Switzerland's international commitment is 
based on the idea that the state can comply with its engagements, all the more necessary as respecting international law is a principle of Swiss law (Art. 5 (4) Const.). As a consequence, determining whether Switzerland will or will not be able to respect its new international commitment is central, and every ratification project should be analysed in terms of its usefulness and necessity from the point of view of the national interest or of the efficiency of cooperation with other state parties. Moreover, only conventions whose ratification is feasible within a reasonable time are suggested.

Furthermore, Article 147 of the Swiss Constitution requires a consultation procedure, with all actors involved, which is coordinated by the Federal Council. Its aim is to test whether the project is correct, executable, and whether it would likely be accepted (Art. 2 Consultation Procedure Act). The consultation procedure is really a key moment for the federal administration, as it gives public administrators an opportunity to point out any fundamental incompatibility between a convention and the domestic legal order. Once the comments and responses have been received, a procedure to iron out the differences is launched, both at the executive and at lower administrative levels. Nevertheless, the current ratification practice makes it possible to submit conventions which are not in line with domestic law to the Federal Assembly for approval. This is notably the case when existing gaps in Swiss law could be filled by directly applicable provisions contained in the treaty. Otherwise, parliamentary approval might be solicited when accompanying legislative measures can be adopted in sufficient time (Federal Council 2016a, b: 6829).

From a procedural point of view, consultation can occur before signature or during the parliamentary phase afterwards (Federal Department of Foreign Affairs 2015: 47). In practice, it usually takes place during the pre-parliamentary phase (see the chapter by Guy-Ecabert in this volume). The actors usually have a three-month period in which they can draft an answer, and cantons, political parties and civil society actors take part, sometimes quite extensively so.

Thus, the signature of a treaty by the Federal Council is part of a much larger political process, much more extensive than the simple signature of a document by a public authority. The procedure shows the implication of different political actors, allowing the Federal Council to evaluate the political support to a treaty. It can reinforce national commitment to a new adhesion and thereby avoid opposition once the international rules 
are 'incorporated' in the domestic legal order. Such a procedure 'a priori' can thus attempt to limit the chances of a referendum that may arise later.

\subsubsection{Ratification}

The second phase is ratification. The main actors are the Federal Assembly, the people and the cantons. Their intervention formally confirms (or overturns) the Federal Council's proposition. It takes its final form with the adoption of a federal decree.

This phase begins with the Federal Assembly's intervention, as it must give its approval to ratification (Ziegler 2015: 90) in the case where the Federal Council has not an exclusive competence (Art. 166 (2) Const.; Art. 24 (2) Parliament Act). To allow the parliament to reach a decision, a document describing the reasons why Switzerland should ratify the treaty in question is drafted by the relevant federal department. This 'federal message' is received by the Federal Council and communicated to the Federal Assembly (Art. 141 Parliament Act). In this communication, the federal administration gives a global evaluation of the treaty text, specifying the content and the scope of every provision. After the Federal Assembly approves the treaty, it adopts a federal decree.

The adoption by the Assembly does not necessarily end matters. In some cases, Swiss constitutional law requires that the citizens and cantons must be consulted. Indeed, a mandatory referendum is required if the treaty in question concerns the accession to an organizations for collective security or joining supranational communities (Art. 140 (1) (b) Const.). On this basis, a referendum was organized in 1992 where citizens voted on joining the European Economic Area. Though strongly supported by the Federal Council, this project was rejected at the polls. Optional referenda (Art. 141 (1) (d) Const.) are also possible, for which 50,000 voters must sign a petition, or eight cantons ask for such a vote, within 100 days of official publication of the federal decree. Signed treaties of an unlimited term or when withdrawal from the treaty is not permitted may be subject to popular vote (those cases were introduced in 1921 and in 1977, respectively). This is also the case for treaties containing important provisions establishing binding legal rules or whose implementation requires the adoption of federal laws (introduced in 2003).

Here, too, the federal administration plays an active role, as it establishes whether the treaty in question must be subjected to a mandatory referendum. If an optional referendum is held, the federal administration 
must verify whether one of three hypothesis take place. Assessing whether a treaty contains important provisions establishing binding legal rules is considered as particularly delicate to assess (Ziegler 2015: 115).

It also has to organize the referendum. Documents must be distributed to all electors in order to allow them to cast their vote validly and in accordance with the respective cantonal procedure (ballot, legitimation card, official voting envelope or validation stamp, etc.). The federal administration provides electors with objective and exhaustive information about the proposed treaty, and by law, this should take into account the main views which have been expressed, including those of the federal Assembly, those of the referendum's initiators and of important minorities (Art 10a and 11 Political Rights Act). Inside the federal administration, the Federal Chancellery is in charge of organizing the referendum, and it takes a selfdefined neutral position in doing so.

While the federal authorities may plead for a strong commitment to multilateralism, the referendum process may show a desire on the part of the population to be more isolationist. The mechanism itself works to the advantage of adhering to international law; it completes the democratic debate by directly connecting the parties concerned. Moreover, it requires of the federal administration that it deliver a clear explanation to the voters explaining Swiss interests in deepening and extending its international relations, but equally evaluating the impact of international law on the domestic legal system. It makes it possible to directly address the potential conflicts between international and national provisions.

A clear institutional dynamic is at work, with its special characteristics deriving from the institutions of federalism and direct democracy. Of these two, direct democracy appears to be of particular relevance for explaining the flexibility in the Swiss ratification system. It allows a soft control over the federal government's actions in its international commitments. The federal administration is a key factor here, though it must combine sometimes contradictory tasks involving monitoring, coordinating, synthesizing and narrating the debate on ratification.

\subsection{The Role of the Federal Administration in the Application of Public International Law}

When applying international norms in the domestic legal system, Swiss law is faced with the traditional issues of international law, namely the direct applicability of the international norm (Sect. 6.4.1). Switzerland, how- 
ever, is also confronted by a particular challenge: the possibility for citizens to launch a popular initiative, even if that initiative potentially contradicts existing international obligations (Sect. 6.4.2).

\subsubsection{The Divect Applicability of International Law and Its Position Within the Domestic Hierarchy of Legal Norms}

The development of international law raised a number of legal questions, most notably about the effect and legal force international norms would have on the domestic order, both in terms of national law and constitutional law. Such issues have a direct effect on the work of public administration, and here the Federal Supreme Court provided a response.

As already mentioned, as far as direct applicability is concerned, Switzerland is in the 'monistic' tradition (Haller 2016: 19). This means no particular act is required for an international rule to be considered valid in the domestic legal system (decision of the Federal Supreme Court case of 27 October 1994: ATF $120 \mathrm{Ib} 360,366$ ). More concretely, the Federal Supreme Court stated that an international provision is directly applicable if sufficiently precise and unconditional to produce a direct effect. In other words, international provisions must permit the constitution of a basis for a concrete decision (decision of the Federal Supreme Court of 2 September 1986: ATF $112 \mathrm{Ib} 183,184$ ). From then on, such conditions determined by the Court have been used by the Federal Council to determine the impact of an international engagement on Switzerland's internal bodies (preliminary report of the Federal Council 2003: 80; ibid. 1994: 1481). In practice, these conditions are verified and explained when a federal message on a ratification is drafted. If the international provisions do not fulfil those criteria, they are considered not self-executing. It is then for the legislators (cantonal and/or federal) to implement the programmatic provisions (this was notably the case when the Federal Council elaborated the ratification project to the 2006 United Nations Convention on the Rights of Persons with Disabilities 2012: 601 et seq.). Furthermore, over time the Federal Supreme Court has promulgated several interpretations about the legal force of international provisions on Switzerland's legal system.

During the 1920-1930s, the Federal Supreme Court considered international treaties to be on equal terms with national legislation. In this perspective, in case of conflict, it applied the interpretation rule lex posterior derogat priori, meaning a later legal rule prevails over an earlier rule. In 1968, the Court recognized the 'principle of interpretation in conformity' with inter- 
national law. In other words, when facing a conflict, the national legal norm must be interpreted in a manner compatible with the relevant international rule. A national legal rule adopted after the ratification of an international treaty shall also be interpreted in conformity. Moreover, if a conforming interpretation is impossible, the Federal Supreme Court confirms the nonapplication of the national rule. By doing so, the Court progressively established the idea of the superiority of international over domestic law. Five years later, in 1973, in the Court's 'Schubert' ruling, it halted this idea of superiority in the event legislators expressly overrode international law. In such cases, the national norm outweighs international law (Decision of the Federal Supreme Court of 2 March 1973: ATF 99 Ib 39).

With the acceleration of the development of international law, the Federal Supreme Court did rule in 1991 that Switzerland cannot avoid its international obligations by applying its domestic law. Domestic law has to be interpreted in conformity with the rules of international law (Decision of the Federal Supreme Court of 26 July 1999: ATF 125 II 417, 424; for an analysis of the case law, see Lammers 2015: 80). If a conforming interpretation is not possible, the Court said that then national rules are not applied. Such a solution has been considered as particularly pertinent when a domestic rule breaches an international rule relating to the protection of human rights (Decisions of the Federal Supreme Court of 26 July 1999: ATF 125 II 417, 424; and 26 July 2002: ATF 128 IV 201, 205). Such an interpretation has been retained in the wording of Article 5 of the Constitution of 1999, which said 'the Confederation and the Cantons shall respect international law' and not 'shall comply' as in art. 49 (1) Const. (Aubert and Mahon 2003: 48 et seq; Thürer 2001: 190).

By 2005, however, the Federal Council was taking a more cautious position, referring to the Schubert ruling, when answering a parliamentary question: 'International law has, in principle, precedence over federal law - at least, if the federal legislation did not knowingly adopt a rule in conflict with international law. The place held by international treaties in the internal hierarchy of norms is controversial in both legal literature and case law. The peremptory norms of public international law (jus cogens) take precedence over all public law rules and set limitations to constitutional revisions' (Federal Council, written answer d.d. 23 April 2005, Official bulletin of the National Council 2005: 212). 


\subsubsection{Constitutional Amendments and International Law}

In practice, it is generally known that Swiss citizens-and, in particular, those political parties failing to find policy decisions which accord with their ideologies-increasingly use the instrument of the popular initiative. One of them, in particular, even seems ready to propose breaching constitutional amendments to achieve its goals.

To prevent an open conflict between international law and the Swiss Constitution, a system to monitor the compliance of popular initiatives with international law has been instituted (Art. 139 (3) Const.). This control is carried out by the Federal Assembly, which verifies that prior to voting, the proposed constitutional provision will not breach the jus cogens. The object of this control is limited to the basic norms and principles of international humanitarian law and the safeguards required by international law not subject to derogation. The parliament has no power to block a popular initiative, but it can formulate a counter-proposal (Auer 2016: 399). To date, only one initiative has been ruled invalid because it was deemed incompatible with a peremptory norm in general international law, namely the nonrefoulement principle (Rhinow and Schefer 2009: 722; Mahon 2014: 115). Other initiatives, which did not violate any of the above-mentioned norms but remained problematic, have been put to vote and, in some cases, adopted. The initiative banning the constructions of minarets, approved by Swiss voters in 2009 (see Art. 73 (3), Const.), is a good example. Clearly targeting one specific religion, the Federal Council judged that it violated norms concerning the freedom of religion as well as the prohibition of discrimination (established in Art. 9 and 14 European Convention on Human Rights (ECHR), but also in 2 and 18 of the UN Covenant II and, possibly, the protection of minorities guaranteed by art. 27 of the Covenant (preliminary report of the Federal Council 2008: 6924)).

In the end, the federal administration, bound by international law, must implement initiatives, respecting the policy aim of the initiative's promoters and the results of the vote. In this case again, the role of the federal administration is important. Indeed, several scenarios to solve a similar situation have been imagined and sometimes tested.

The first scenario is to imagine implementation laws in conformity with international law. This delicate strategy was used to deal with the initiative for the automatic expulsion of foreign criminal offenders, voted in 2008 (Art. 121 Const.). The application of the new constitutional provision can expose some individuals to a dangerous return to a state where they could potentially be threatened with violence or persecution. To avoid this 
hypothesis, the federal administration applies the norm by implementing the expulsion decision only if the individual's life is not endangered in the country of origin (Hertig Randall and McGregor: 431).

The second scenario, untested today, is to renegotiate or withdraw from the treaties that are in conflict with a newly adopted constitutional norm. The Federal Council began a political discussion with the Federal Assembly in 2015 (Conseil des Etats 2016), which has initiated a bill on the competence to renounce a treaty (Conseil des Etats 2018). The option of renegotiation was evoked when the popular initiative for 'ending mass immigration' was adopted in 2014, requiring the implementation of immigration quotas and giving Swiss workers priority in employment. This new article $12 \mathrm{la}$ is viewed as particularly problematic, given the bilateral agreements - especially on the free movement of persons - between Switzerland and the EU, which gives Switzerland access to the single market (Maiani 2013) and also other treaties as the ECHR, the UN Covenant II and the Convention on the Rights of the Child (Erhenzeller et al. 2014: 2196). Nevertheless, given the potential impact of this norm on the Swiss economy, one dependent on commerce with the EU member states, the application of this provision required considerable negotiation between the Federal Council and the EU. After long and intense diplomatic exchanges, the Federal Administration found a solution. They chose to adopt a regulation compatible with the current agreement, thereby maintaining good relationships with the EU without completely negating the new provision in the Swiss constitution.

A third scenario was foreseen by extending the recognized grounds for invalidating popular initiatives. This proposal was abandoned in 2014, after the federal administration discovered during the consultation process that there were fundamental and unbridgeable differences of opinions among the actors involved (Commission des institutions politiques du Conseil d'Etat 2015: 6493).

Finally, 'popular initiatives which are incompatible with Switzerland's international obligation are not new, the violation of international law has in the past been rather accidental than intentional' (Hertig Randall and McGregor 2010: 429). An initiative calling for 'Swiss law instead of foreign judges (self-determination initiative)' is part of the current trend (Kolb 2016). Its aim is to produce a constitutional amendment which would establish the primacy of national constitutional law over international law, thereby reversing the historical trend integrating international law in Swiss law. 


\subsection{Conclusion}

Swiss law shows a variety of interesting norms visible when dealing with the impact of international law on domestic legislation. The distribution of roles and competencies demonstrates sophisticated institutional engineering in terms of treaty ratification. The risk in activating direct democracy mechanisms can be seen as the reason justifying this complex system. With this in mind, direct democracy can be considered as producing a positive, legitimizing effect on the recognition of the place of international law in the domestic order. This allows one to dismiss the argument often put forward by detractors who frequently assert international law is produced by technocratic decision-makers and lacks democratic legitimacy.

The effect of direct democracy can also be unwholesome, particularly in the case of popular initiatives, and serve to promote minority ideologies, whether progressive or conservative. Currently, in the human rights domain, the use of the popular initiative is aimed at calling into question Switzerland's foreign policy engagements, or to reject the autonomous developments of international law. It has advocated an ideology of retreat into national self-interest, in opposition to the humanist perspective found in contemporary international law, echoing the humanitarian tradition of the country, another founding principle of the Swiss constitutional order.

In this particularly tense situation, the federal administration plays a key role. Like a mediator, avoiding the confrontation between actors and legal norms, it contributes to finding a compromise. The key challenge for the federal administration is to maintain this position of equilibrium between the international openness of Switzerland regarding its humanitarian and neutrality traditions and its adherence to a political system defined by its direct democracy mechanisms. From this point of view, the political context seems to show the popular initiative will still represent a challenge in the future.

\section{REFERENCES}

Aubert, J.-F., \& Mahon, P. (2003). Petit Commentaire de la Constitution fédérale de la Confédération suisse du 18 avril 1999. Zurich/Basel/Genève: Schulthess. Auer, A. (2016). The people have spoken: Abide? A critical view of the EU's dramatic referendum (in)experience. European Constitutional Law Review, 12(3), 397-408. 
Commission des institutions politiques du Conseil des Etats. (2015). Conditions de validité des initiatives populaires. Examen du besoin de légiférer du 20 août 2015. Fenille fédérale, 6485-6512.

Commission des institutions politiques du Conseil des Etats. (2016). Initiative parlementaire 16.456. Dénonciation et modification des traités internationaux. Répartition des compétences.

Commission des institutions politiques du Conseil des Etats. (2018). Rapport et procédure de consultation. Dénonciation et modification des traités internationaux. Répartition des compétences. https://www.parlament.ch/fr/organe/ commissions/commissions-thematiques/commissions-cip/rapports-consultations-cip/vernehmlassung-spk-16-456. Accessed 30 Mar 2018.

Ehrenzeller, B., Hettich, P., \& Schweizer, R. J. (2014). Art. 121 a. In B. Erhenzeller, B. Schindler, R. J. Schweizer, \& K. A. Vallender (Eds.), Die Schweizerische Bundesverfassung. St Galler Kommentar (pp. 2190-2212). Zürich/St.Gallen: Dike/Schulthess.

Federal Council. (1994). Message du 22 juin 1994 concernant les initiatives populaires "pour une politique d'asile raisonnable" et "contre l'immigration clandestine”. Fenille Fédérale, III, 1471-1513.

Federal Council. (1997). Message du Conseil fédéral du 20 novembre 1996 relatif à une nouvelle constitution fédérale. Fenille fédérale I, 1-653.

Federal Council. (2001). Rapport du 2 avril 2001 sur Initiative parlementaire (Commission 96.091 CE) Suppression de carences dans les droits populaires. Feuille fédérale, 5783-5800.

Federal Council. (2003). Message du Conseil fédéral à l'Assemblée fédérale, du 19 décembre 2003, relatif à l'approbation de la Charte européenne de l'autonomie locale. Fenille fédérale, 71-92.

Federal Council. (2005). Réponse écrite donnée par le Conseil fédéral, le 23 février 2005, à une interpellation déposée le 17 décembre 2004 par M. Mörgeli, député au Conseil national. Bulletin officiel, 212-213.

Federal Council. (2008). Message fédéral relatif à l'initiative populaire "contre la construction des minarets". Fenille fédérale, 6923-6970.

Federal Council. (2016a). Onzième rapport sur la Suisse et les conventions du Conseil de l'Europe du 24 août. Fenille fédérale, 6823-6862.

Federal Council. (2016b). Avis du 31 août 2016 sur l'interpellation 16.3304 (développement de la réglementation). https://www.parlament.ch/fr/ratsbetrieb/ suche-curia-vista/geschaeft?AffairId=20163304. Accessed 30 Mar 2018.

Federal Department of Foreign Affairs. (2015). Guide de la pratique en matière de traités internationaux. https://www.eda.admin.ch/eda/fr/home/dienstleistungen-publikationen/publikationen.html/publikationen/fr/eda/voelkerrecht/Praxisleitfaden-Voelkerrechtliche-Vertraege.html. Accessed 30 Mar 2018.

Haller, W. (2016). The Swiss constitution in a comparative context. Zurich/St Gall: Dike. 
Hertig Randall, M. (2016). The Swiss federal bill of rights in the context of international human rights protection: Added value and shortcomings. Revue interdisciplinaire d'études juridiques, 77(2), 151-177.

Hertig Randall, M., \& McGregor, E. (2010). Reconciling direct democracy and fundamental rights: The case of the Swiss Minaret initiative. Tijdschrift voor Constitutioneel Recht (TvCR), 4, 428-436.

Kolb, R. (2016). L'initiative de l'UDC sur l'autodétermination ( « juges étrangers »). Swiss Review of International and European Law, 26, 567-570.

Lammers, G. (2015). La démocratie directe et le droit international. Prise en compte des obligations internationales de la Confédération et la participation populaire à la politique extérieure. Berne: Staempfli.

Mader, L. (2013). Législation. In A. Ladner, J.-L. Chappelet, Y. Emery, P. Knoepfel, L. Mader, N. Soguel, \& F. Varone (Eds.), Manuel d'administration publique Suisse (pp. 245-265). Lausanne: Presses polytechniques et universitaires romandes.

Mahon, P. (2014). Droit Constitutionnel. Bâle: Helbing Lichtenhahn.

Maiani, F. (2013). Internationalisation du droit suisse. In A. Ladner, J.-L. Chappelet, Y. Emery, P. Knoepfel, L. Mader, N. Soguel, \& F. Varone (Eds.), Manuel d'administration publique Suisse (pp. 283-298). Lausanne: Presses polytechniques et universitaires romandes.

Maiani, F., \& Bieber, R. (2016). Précis de droit européen. Bern: Stämpfli.

Rhinow, R., \& Schefer, M. (2009). Schweizerisches Verfassungsrecht. Basel: Helbing Lichtenhahn.

Thürer, D. (2001). Verfassungsrecht und Völkerrecht. In D. Thürer, J.-F. Aubert, \& J. P. Müller (Eds.), Verfassungsrecht der Schweiz, Droit constitutionnel suisse (pp. 179-206). Zürich: Schulthess.

Ziegler, A. (2015). Introduction au Droit International Public. Bern: Stämpfli.

Open Access This chapter is licensed under the terms of the Creative Commons Attribution 4.0 International License (http://creativecommons.org/licenses/ by $/ 4.0 /)$, which permits use, sharing, adaptation, distribution and reproduction in any medium or format, as long as you give appropriate credit to the original author(s) and the source, provide a link to the Creative Commons license and indicate if changes were made.

The images or other third party material in this chapter are included in the chapter's Creative Commons license, unless indicated otherwise in a credit line to the material. If material is not included in the chapter's Creative Commons license and your intended use is not permitted by statutory regulation or exceeds the permitted use, you will need to obtain permission directly from the copyright holder.

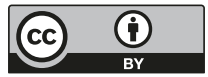

